\title{
PENINGKATAN KAPASITAS APARATUR DAERAH DALAM PENYELENGGARAAN PELAYANAN PUBLIK ${ }^{1}$
}

\author{
Oleh: Drs. Desi Fernanda, M.Soc.Sc. ${ }^{2}$
}

\begin{abstract}
The main purpose of regional autonomy is delivering better, faster, cheaper and closer public services as well as improving public welfare. To adroitly provide high-quality public service, both government officials and community members need to comprehend the basic concept and scope of services, and the principles of performance measurement regarding deliverance of public service. Besides, philosophical grounds on why government should carry out

public services tasks are really matter to be recognized. Based on such common understanding, this paper offers some strategies concerning capacity building for service provider, i.e. government apparatus.
\end{abstract}

Keywords: pelayanan publik, kapasitas aparatur, desentralisasi.

\section{Pengantar}

Secara universal keberadaan pemerintahan daerah pada dasarnya adalah dalam rangka penyelenggaraan pelayanan publik (provision of public services) bagi kesejahteraan masyarakat. Sejalan dengan hal itu, UU Nomor 32 Tahun 2004 menetapkan dalam Pasal 1 Ayat (3) bahwa: "Pemerintah daerah ... menjalankan otonomi seluas-luasnya, kecuali urusan pemerintahan yang menjadi urusan Pemerintah, dengan tujuan meningkatkan kesejahteraan masyarakat, pelayanan umum, dan daya saing daerah”. Sebelumnya, dalam Penjelasan UU Nomor 22 Tahun 1999, yang digantikan oleh UU tersebut di atas, dinyatakan bahwa pemberian otonomi kepada daerah bertujuan untuk: "meningkatkan pelayanan dan kesejahteraan masyarakat yang semakin baik, mengembangkan kehidupan demokrasi, keadilan, dan pemerataan, dan memelihara hubungan yang serasi antara Pusat dan Daerah serta antar Daerah dalam rangka menjaga keutuhan Negara Kesatuan Republik Indonesia (NKRI)”.

\footnotetext{
Makalah ini merupakan modifikasi dari kertas kerja penulis yang dipresentasikan pada forum "Rapat Penyusunan Panduan Peningkatan Kinerja Pemerintah Daerah di Bidang Pelayanan Publik”, diselenggarakan oleh Direktorat Jenderal Pemerintahan Umum, Depdagri, di Jakarta, 31 Mei - 2 Juni 2005.

2 Kepala Pusat Kajian dan Pendidikan dan Pelatihan Aparatur I LAN Bandung; sedang menyelesaikan Program Pascasarjana (S-3) di Universitas Padjadjaran, Bandung; sejak tahun 2003 melaksanakan tugas sebagai Ketua Tim Pelaksana National Resource Center (NRC) dan Anggota Tim Teknis NCBRB Proyek Sustainable Capacity Building (SCBD) kerjasama LAN, Depdagri, dan ADB; serta anggota Komite Reformasi Birokrasi (Koreksi) di Partnership for Governance Reform - UNDP sejak tahun 2002.
} 
Meskipun kedua UU tersebut memiliki perbedaan dalam rumusannya, namun pada hakekatnya terdapat kesamaan, bahwa tujuan penyelenggaraan pemerintahan daerah dengan otonomi yang seluas-luasnya adalah untuk meningkatkan kesejahteraan masyarakat, dan operasionallisasinya diwujudkan melalui penyelenggaraan pelayanan publik. Hal ini didasarkan kepada kenyataan bahwa Pemerintah Daerah, terutama daerah Kabupaten dan Kota, adalah unit organisasi pemerintahan yang paling dekat dengan masyarakat, sehingga dinilai paling mampu menterjemahkan aspirasi dan kepentingan masyarakat setempat yang perlu dilayani atau dipenuhi oleh pemerintah. Permasalahan di daerah yang satu tentunya akan berbeda dengan apa yang berlaku di daerah lainnya, demikian juga aspirasi dan kepentingan masyarakatnya. Seandainya kondisi ini harus dilayani atau ditangani oleh Pemerintah Pusat maka pelayanan publik yang diselenggarakan mungkin tidak akan efektif. Pemerintah berdasarkan UU Nomor 32 Tahun 2004 berperan dalam menetapkan standar pelayanan minimal serta fungsi-fungsi pengaturan, pembinaan, dan pengendalian kinerja penyelenggaraannya oleh Pemerintah Daerah.

Sejalan dengan kebijakan otonomi daerah dewasa ini, kertas kerja ini akan mencoba membahas apa dan bagaimana pengertian serta ruang lingkup, maupun prinsip-prinsip kinerja dan kualitas pelayanan publik untuk memperoleh kesamaan persepsi dan cara pandang aparatur daerah dalam penyelenggaraan pelayanan publik di daerah. sehingga dapat dirumuskan rekomendasi dalam rangka peningkatan kapasitas aparatur daerah. Selanjutnya akan dibahas pengertian dan ruang lingkup peningkatan kapasitas (capacity building) secara konseptual maupun praksis, sehingga dapat dirumuskan beberapa langkah rekomendasi peningkatan kapasitas aparatur daerah dalam penyelenggaraan kebijakan publik.

\section{Konsep dan Ruang Lingkup Pelayanan Publik}

Pelayanan publik (Public Services), berdasarkan Keputusan Menteri Pendayagunaan Aparatur Negara (MenPAN) nomor 63/KEP/M.PAN/7/2003, diartikan sebagai: “Segala kegiatan pelayanan yang dilaksanakan oleh penyelenggara pelayanan publik sebagai upaya pemenuhan kebutuhan penerima pelayanan maupun pelaksanaan ketentuan peraturan perundang-undangan”. Pada hakekatnya, pelayanan publik adalah pemberian pelayanan prima kepada masyarakat yang merupakan kewajiban aparatur negara sebagai abdi masyarakat.

Pelayanan publik dapat diklasifikasikan kedalam tiga kelompok, yaitu:

1. Kelompok Pelayanan Administratif yaitu pelayanan yang menghasilkan berbagai bentuk dokumen resmi yang dibutuhkan oleh publik, misalnya status kewarganegaraan, sertifikat kompetensi, kepemilikan atau penguasaan terhadap suatu barang dan sebagainya. Dokumen-dokumen ini antara lain KTP, Akte Pernikahan, Akte Kelahiran, Akte Kematian, BPKB, SIM, STNK, IMB, Paspor, Sertifikat Pemilikan Tanah, dan sebagainya.

2. Kelompok Pelayanan Barang yaitu pelayanan yang menghasilkan berbagai bentuk/jenis barang yang digunakan oleh publik, misalnya jaringan telepon, tenaga listrik, air bersih, dan sebagainya. 
3. Kelompok Pelayanan Jasa yaitu pelayanan yang menghasilkan berbagai jasa yang dibutuhkan oleh publik, misalnya pendidikan, pemeliharaan kesehatan, penyelenggaraan transportasi, pos, dan sebagainya.

Sebenarnya, selain dari ketiga kelompok pelayanan publik tersebut, masih ada satu jenis pelayanan publik yang secara nyata sudah dilaksanakan oleh seluruh jajaran pemerintahan, yaitu kelompok pelayanan yang bersifat pengaturan (Regulasi). Jenis pelayanan ini dilaksanakan melalui penerbitan berbagai ketentuan hukum dan peraturan perundangundangan, maupun kebijakan publik yang mengatur sendi-sendi kehidupan masyarakat sehingga terciptanya ketertiban, keteraturan, dan ketentraman dalam masyarakat, serta upaya pencegahan untuk melindungi masyarakat dari berbagai macam ancaman terhadap keselamatan diri maupun lingkungannya. Pelaksanaan pelayanan regulasi ini dilakukan melalui sosialisasi produk-produk hukum, penegakan hukum, penyidikan, penyelidikan, dan penindakan pelanggaran hukum dan perundang-undangan, dan sebagainya.

Pelayanan publik berdasarkan pengertian maupun ruang lingkup sebagaimana telah disebutkan, dengan demikian pada hakekatnya adalah merupakan operasionalisasi kebijakan publik yang ditetapkan dan dikelola oleh masing-masing unsur perangkat pemerintah daerah. Pelayanan yang diselenggarakan oleh pemerintah daerah tersebut diwujudkan dalam bentuk penyediaan barang atau jasa yang merupakan kebutuhan hajat hidup masyarakat. Secara teoritik, barang atau jasa yang menjadi kebutuhan masyarakat tersebut sesungguhnya terdiri dari empat kategori berdasarkan karakteristik pola konsumsi (consumption) dan pola eksklusi atau akses pemilikannya (exclusion) sebagaimana dikemukakan oleh E.S.Savas (1987, 35-57) sebagai berikut:

1. Barang/jasa Privat (Private Goods), yaitu barang atau jasa yang pola konsumsinya dilakukan secara individual (Individual Consumption) dan pemilikannya atau penggunaannya dapat dengan mudah ditetapkan kepada orang-orang tertentu oleh penyedia (Supplier) barang atau jasa tersebut melalui transaksi dan pembebanan biaya (Exclusion). Contoh barang atau jasa privat ini antara lain: makanan, pakaian, rumah, ikan, air minum botolan, pasokan listrik dari generator pribadi, pemilikan kendaraan pribadi, pengobatan penyakit, jasa dokter pribadi, ijasah pendidikan, jasa guru privat, sertifikat tanah, ijin mengemudi (SIM), ijin berburu di hutan, akta kelahiran, dan sebagainya.

2. Barang/jasa Tol (Toll Goods), yaitu barang atau jasa yang dapat dikonsumsi secara bersama-sama sekaligus dengan orang lain (Joint Consumption) dan pemilikan ataupun penggunaannya dapat dengan mudah ditetapkan oleh penyedia (Supplier) barang atau jasa tersebut melalui transaksi dan pembebanan biaya (Exclusion). Contoh barang/jasa kategori ini antara lain: jasa sambungan telepon, siaran televisi kabel (Cable TV), pasokan air bersih (PAM), pasokan listrik, tempat pemakaman umum (TPU), jasa pemeriksaan/pemeliharaan kesehatan umum (poliklinik, rumah sakit/puskesmas), jasa pendidikan umum maupun kejuruan, jalan/jembatan tol, tempat hiburan umum (bioskop, taman hiburan, fasilitas olahraga tertentu), gedung parkir kendaraan, jasa angkutan umum, terminal angkutan umum darat, laut/sungai/danau, dan udara, dan sebagainya.

3. Barang/jasa Umum (Common-Pool Goods), yaitu barang atau jasa yang dikonsumsi secara individual (Individual Consumption) namun pemilikan atau penggunaan/pemanfaatannya sangat sulit untuk ditetapkan atau dibatasi kepada orangorang tertentu dan untuk memperolehnya tidak diperlukan transaksi atau pembebanan biaya (Non-Exclusion). Contoh barang/jasa yang termasuk kategori ini antara lain adalah: ikan di dalam laut, sungai, dan danau (kecuali ikan di kolam/danau milik pribadi), oksigen di udara, buah-buahan atau umbi-umbian di hutan, binatang buruan di hutan sepanjang tidak dilarang atau di lindungi oleh Undang-undang, dan sebagainya. 
4. Barang/jasa Kolektif (Collective Goods), yaitu barang atau jasa yang dikonsumsi secara bersama-sama (Joint Consumption) dan penggunaan atau pemanfaatannya tidak dapat ditetapkan hanya kepada orang-orang tertentu serta tidak diperlukan transaksi maupun pembebanan biaya kecuali melalui pajak (Non-Exclusion). Contoh jenis barang atau jasa ini adalah: urusan pertahanan, patroli keamanan oleh polisi; jasa pemadam kebakaran; penyelenggaraan pemasyarakatan residivis (penjara); penyediaan pertamanan umum; jalan/jembatan umum; penerangan jalan umum; imunisasi/vaksinasi pencegahan penyakit menular (epidemik), parkir di jalan umum, fasilitas dan sebagainya.

Tidak semua kategori barang dan jasa tersebut di atas dapat disediakan atau diselenggarakan oleh pemerintah maupun pemerintah daerah. Bahkan sebagian besar kategori barang dan jasa tersebut dewasa ini boleh dikatakan telah dapat diselenggarakan ataupun disediakan oleh berbagai institusi dunia usaha maupun lembaga kemasyarakatan. Namun demikian berdasarkan argumentasi tertentu, pemerintah dan pemerintah daerah di berbagai belahan dunia masih berperan sebagai penyedia dan penyelenggara pelayanan publik untuk memenuhi kebutuhan dan aspirasi masyarakat atas barang dan jasa dari berbagai kategori tersebut, terutama yang termasuk Common Pool Goods dan Collective Goods. Argumentasi yang menjadi dasar legitimasi bagi pemerintah ataupun pemerintah daerah untuk menyelenggarakan pelayanan publik sebagai manifestasi kebijakan publik tersebut adalah: argumen mengenai eksternalitas, argumen inefisiensi pasar, dan argumen monopoli. Masingmasing argumentasi tersebut dapat dijelaskan sebagai berikut:

1. Argumen Eksternalitas mendasarkan bahwa dampak negatif yang terjadi sebagai akibat atau sebagai konsekuensi kegiatan dalam pasar atau di lingkungan masyarakat, yang dapat dirasakan oleh pihak lain yang tidak terlibat langsung dalam transaksi atau aktivitas tersebut, biasanya sangat sulit atau tidak mungkin dapat diatasi langsung oleh unsur-unsur yang bertransaksi dalam sistem pasar. Karena itu, dalam rangka melindungi kepentingan publik maka pemerintah atau pemerintah daerah dapat berperan mengambil keputusan yang dikenal sebagai kebijakan publik untuk menyelenggarakan pelayanan publik tertentu bagi masyarakat, misalnya: layanan pemadaman kebakaran, pelarangan merokok di tempat-tempat umum (ruang publik), reboisasi hutan, reklamasi hutan dan lingkungan hidup yang rusak akibat tindakan manusia maupun gejala alam, penyelenggaraan tempat penyembelihan hewan (pejagalan umum), pengendalian dan pengawasan obat-obatan dan makanan, penanggulangan bencana baik penyakit epidemik maupun bencana alam, pengendalian kelestarian sumber daya kelautan maupun kehutanan, dan sumber daya alam lainnya, dan sebagainya.

2. Argumen Inefisiensi Pasar, yang dimaksud adalah jika pada kenyataannya sistem pasar tidak memiliki kompetensi yang memadai untuk memenuhi kebutuhan masyarakat, karena satu dan lain hal, maka menjadi kewajiban pemerintah untuk melakukan intervensi penyediaan pelayanan publik guna memenuhi kebutuhan masyarakat. Alasan ini terjadi sebagai akibat kurangnya pemahaman pasar atau dunia usaha maupun potensi-potensi dalam masyarakat mengenai kondisi yang dihadapi sehingga tidak mampu memenuhi tuntutan kebutuhan atau permintaan (demand) masyarakat konsumen. Jenis pelayanan publik yang diselenggarakan pemerintah atau pemerintah daerah berdasarkan argumen ini, antara lain adalah: penyediaan fasilitas pasar tradisional, penyediaan sarana angkutan massal (mass rapid transportation), penyediaan fasilitas terminal angkutan umum, baik darat, laut/danau/sungai, maupun udara, penyediaan jalan bebas hambatan, penyediaan gelanggang olahraga umum, penyelenggaraan museum, penyediaan pertamanan umum dan sebagainya.

3. Argumen Monopoli umumnya berkaitan dengan tidak adanya kemampuan institusi pasar maupun masyarakat untuk menyediakan atau mensuplai kebutuhan masyarakat itu sendiri; atau disebabkan oleh tidak adanya sistem persaingan dalam penyediaan barang dan jasa bagi masyarakat karena tidak ada unsur pelaku pasar yang mampu masuk kedalam bisnis 
tersebut. Alasan yang umum adalah karena nilai investasi yang terlalu tinggi, potensi kerugian yang besar atau laba yang terlalu kecil, serta nilai resiko usaha yang terlalu besar. Namun demikian, tidak adanya persaingan dalam pasar dikhawatirkan akan menimbulkan terjadinya monopoli atau oligopoli, serta tindakan sewenang-wenang dunia usaha yang dapat merugikan masyarakat. Dalam keadaan tersebut pemerintah atau pemerintah daerah dapat melakukan inisiatif atau intervensi berupa tindakan kebijakan untuk menyelenggarakan sendiri pelayanan publik guna memenuhi tuntutan kebutuhan masyarakat. Dalam hal ini monopoli dilakukan oleh pemerintah atau pemerintah daerah sendiri dalam penyelenggaraan pelayanan publik. Contoh tindakan pemerintah atau pemerintah daerah berdasarkan argumen ini, antara lain: penetapan kebijakan Upah Minimum sebagai pedoman pemberian kompensasi terhadap para pekerja di sektor swasta; penyelenggaraan angkutan massal jalan rel (kereta api), dalam konteks Indonesia dilaksanakan oleh PT KA; penyelenggaraan bendungan air untuk keperluan pembangkitan listrik, pengairan sawah, penyediaan air baku industri, dan sebagainya; penyelenggaraan jasa pengadaan air bersih oleh PDAM; penyelenggaraan jasa kebersihan lingkungan, termasuk pengelolaan persampahan; penyelenggaraan perijinan bangunan (pengelolaan IMB); penyelenggaraan pengelolaan terminal angkutan umum orang dan barang, baik darat, laut/sungai/danau, maupun udara; dan sebagainya.

Telah dikemukakan sebelumnya bahwa pelayanan publik yang diselenggarakan oleh pemerintah maupun pemerintah daerah pada umumnya adalah barang dan jasa Publik yang termasuk ke dalam kategori-kategori Common Pool Goods dan Collective Goods. Kecuali di negara-negara sosialis/komunis, maka pemerintah maupun pemerintah daerah adalah satusatunya penyelenggara pelayanan publik (Sole Provider of Public Services) untuk barang dan jasa dari semua kategori. Sedangkan pemerintah dan pemerintah daerah di berbagai negara maju pada umumnya membatasi peranan pada penyelenggaraan pelayanan publik untuk barang dan jasa yang merupakan kebutuhan dasar masyarakat yang pada umumnya termasuk dalam kategori barang/jasa kolektif (Collective Goods) dan umum (Common-pool Goods).

Di negara-negara demokrasi yang sedang berkembang, peranan pemerintah maupun pemerintah daerah dalam penyelenggaraan pelayanan publik biasanya cenderung berkembang bukan hanya dalam pengelolaan dan penyediaan barang dan jasa yang termasuk kategori common-pool goods dan collective goods, melainkan juga sebagian barang dan jasa yang termasuk toll-goods dan bahkan private goods. Ekspansi intervensi pemerintah dan pemerintah dalam penyediaan barang dan jasa tersebut antara lain disebabkan karena kurang berkembangnya kapasitas dan mekanisme pasar maupun lembaga-lembaga kemasyarakatan untuk menyediakan kebutuhan masyarakat.

Namun demikian, sejalan dengan perkembangan persepsi masyarakat terhadap nilai strategis dan pengaruh barang atau jasa tertentu bagi kesejahteraan masyarakat dan dalam rangka national capacity building, maka banyak negara-negara maju seperti Amerika Serikat, Canada, Jepang, maupun negara-negara di Eropa yang mengembangkan pelayanan publik untuk menyediakan atau mengelola barang dan jasa yang termasuk kategori private goods dan toll goods dalam batas-batas tertentu yang tidak menyebabkan distorsi terhadap sistem pasar.

Di Indonesia, selama ini peran serta masyarakat dan institusi pasar dalam penyediaan berbagai jenis barang dan jasa dari berbagai kategori yang ada sesungguhnya telah demikian berkembang. Namun dalam perkembangan terakhir, khususnya dalam era otonomi dan ditengah-tengah keterbatasan kemampuan keuangan negara, telah berkembang tuntutan masyarakat yang menghendaki intervensi pemerintah maupun pemerintah daerah melalui kebijakan membebaskan berbagai beban biaya untuk memperoleh layanan publik di bidang pendidikan dan kesehatan. Di samping itu, berkembang pula tuntutan masyarakat agar pemerintah dapat mempertahankan subsidisasi atas pengadaan bahan-bahan kebutuhan pokok masyarakat lainnya. Perkembangan kondisi tersebut di atas, dapat dibuktikan di beberapa daerah yang telah menerapkan kebijakan pelayanan publik berupa antara lain: pembebasan 
SPP Sekolah Dasar, bahkan pembebasan biaya pendidikan mulai SD hingga SMU; penyelenggaraan angkutan pelajar secara gratis; pembebasan biaya pemeriksaan dan pengobatan di Puskesmas; termasuk pembebasan biaya perijinan usaha maupun biaya IMB bagi para investor yang akan membangun industri di daerah yang bersangkutan. Namun di lain pihak, banyak daerah yang mengeluarkan kebijakan pelayanan administratif yang justru melanggar norma perpajakan dan cenderung melakukan intervensi pelayanan publik yang mendistorsi pasar.

Perkembangan tersebut di atas sesungguhnya memberikan indikasi perlunya pengembangan kapasitas bagi aparatur daerah dalam penyelenggaraan pelayanan publik, baik yang menyangkut kapasitas perumusan kebijakan publik, pengelolaan pelaksanaan pelayanan publik, peningkatan daya jangkau dan kemanfaatan, serta peningkatan kualitas pelayanan publik didaerah.

\section{Prinsip Kinerja dan Kualitas Pelayanan Publik}

Secara umum prinsip pelayanan publik yang dikenal di kalangan pemerintahan daerah adalah jargon pelayanan publik yang lebih baik (berkualitas), lebih cepat, dan lebih murah (Better, Faster, and Cheaper). Namun demikian sesungguhnya berdasarkan Kepmenpan Nomor 63/KEP/M.PAN/7/2003, yang dimaksud dengan prinsip pelayanan publik adalah mencakup aspek-aspek sebagai berikut:

1. Kesederhanaan, dimana prosedur pelayanan publik tidak berbelit-belit, mudah dipahami, dan mudah dilaksanakan.

2. Kejelasan, dalam hal ini meliputi kejelasan mengenai (a) persyaratan teknis dan administratif pelayanan publik; (b) unit kerja/pejabat yang berwenang dan bertanggungjawab dalam memberikan pelayanan dan penyelesaian keluhan/ persoalan/sengketa dalam pelaksanaan pelayanan publik; dan (c) rincian biaya pelayanan publik dan tata cara pembayarannya.

3. Kepastian Waktu, yaitu bahwa pelaksanaan pelayanan publik dapat diselesaikan dalam kurun waktu yang telah ditentukan.

4. Akurasi, bahwa produk pelayanan publik diterima dengan benar, tepat, dan sah.

5. Keamanan, bahwa proses dan produk pelayanan publik memberikan rasa aman dan kepastian hukum.

6. Tanggungjawab, bahwa pimpinan penyelenggara pelayanan publik atau pejabat yang ditunjuk dapat dan harus dapat bertanggungjawab atas penyelenggaraan pelayanan dan penyelesaian keluhan/persoalan dalam pelaksanaan pelayanan publik.

7. Kelengkapan sarana dan prasarana, yaitu ketersediaan sarana dan prasarana kerja, peralatan kerja dan pendukung lainnya yang memadai termasuk penyediaan sarana pendukung lainnya yang memadai termasuk penyediaan sarana teknologi telekomunikasi dan informatika (telematika).

8. Kemudahan Akses, dalam hal ini tempat dan lokasi serta sarana pelayanan harus memadai, mudah dijangkau oleh masyarakat, dan dapat memanfaatkan teknologi telekomunikasi dan informatika.

9. Kedisiplinan, Kesopanan dan Keramahan dimana pemberi pelayanan harus bersikap disiplin, sopan dan santun, ramah, serta memberikan pelayanan dengan ikhlas.

10. Kenyamanan, dalam hal ini lingkungan pelayanan harus tertib, teratur, disediakan ruang tunggu yang nyaman, bersih, rapi, lingkungan yang indah dan sehat serta dilengkapi dengan fasilitas pendukung pelayanan, seperti parkir, toilet, tempat ibadah, dan lain-lain.

Untuk dapat melaksanakan prinsip-prinsip pelayanan publik secara baik, tepat dan

benar sehingga mampu memberikan kepuasan yang optimal kepada masyarakat pengguna 
pelayanan publik; maka para penyelenggara pelayanan publik harus mampu menetapkan standar-standar pelayanan publik yang diselenggarakannya itu. Sebagai pedoman berdasarkan Keputusan Menteri Pendayagunaan Aparatur Negara tersebut di atas, standar pelayanan publik adalah sekurang-kurangnya mencakup hal-hal sebagai berikut:

1. Prosedur pelayanan: Prosedur pelayanan yang dibakukan bagi pemberi dan penerima pelayanan termasuk pengaduan.

2. Waktu penyelesaian: ditetapkan sejak saat pengajuan permohonan sampai dengan penyelesaian pelayanan termasuk pengaduan.

3. Biaya pelayanan dalam hal ini biaya/tarif pelayanan termasuk rinciannya yang ditetapkan dalam proses pemberian layanan.

4. Produk pelayanan, hasil pelayanan yang akan diterima sesuai dengan ketentuan yang telah ditetapkan.

5. Sarana dan Prasarana harus disediakan secara memadai oleh penyelenggara pelayanan publik.

6. Kompetensi petugas pemberi pelayanan, harus ditetapkan dengan tepat berdasarkan pengetahuan, keahlian, keterampilan, sikap, dan perilaku yang dibutuhkan.

Aspek-aspek standar pelayanan publik tersebut secara keseluruhan haruslah merupakan satu kesatuan paket pelayanan institusi pemerintah/pemerintah daerah kepada masyarakat yang harus selalu dipelihara serta dikembangkan kualitasnya. Standar-standar pelayanan tersebut perlu dikembangkan sebagai komitmen institusi penyelenggara pelayanan publik, untuk mencakup aspek-aspek kualitas dan jaminan kemanfaatan yang dapat dirasakan secara langsung maupun tidak langsung oleh masyarakat penerima layanan publik yang bersangkutan.

Secara teoritik, keenam aspek standar pelayanan publik yang dikemukakan dalam Keputusan Menpan tersebut di atas, baru mencakup aspek-aspek inputs atau aspek-aspek penunjang dan pelengkap dari satu paket pelayanan publik. Menurut pandangan pakar manajemen pelayanan di Amerika Serikat, James A Fitzsimmons dan Mona J. Fitzsimmons (1994) sebagaimana dibahas dalam buku mereka yang berjudul "Service Management For Competitive Advantage”, kinerja dan kualitas suatu pelayanan publik tidak dapat hanya dipandang dari aspek-aspek penunjang atau pelengkap, atau kuantitas dan kualitas barang/jasa yang disediakan secara terpisah-pisah; melainkan sebagai satu kesatuan paket pelayanan yang mencakup empat aspek, yaitu: (1) Fasilitas penunjang (Supporting Facilities); (2) Barang/jasa Pelengkap (Complimentary Products/Services); (3) Wujud layanan secara nyata (Explicit Services); dan (4) Wujud layanan berupa manfaat yang tersirat (Implicit Services). Penjelasan mengenai paket pelayanan tersebut sebagai satu kesatuan adalah sebagai berikut:

1. Fasilitas Penunjang (Supporting Facilities): Fasilitas penunjang ini adalah berbagai prasarana dan sarana fisik (Infrastruktur) yang harus sudah tersedia sebelum sesuatu pelayanan publik tertentu dapat diselenggarakan atau ditawarkan kepada masyarakat. Fasilitas penunjang untuk berbagai jenis layanan publik antara lain sebagai berikut: Bangunan Rumah Sakit/Puskesmas lengkap dengan berbagai fasilitas untuk pemeriksaan dan perawatan pasien; Ruang tunggu yang nyaman dilengkapi dengan bangku-bangku atau sofa untuk tempat duduk para pengguna layanan, yang dilengkapi dengan kipas angin atau pengatur udara (AC) serta pesawat televisi, serta toilet yang bersih; Fasilitas parkir yang dilengkapi garis-garis pembatas yang jelas; Layanan air bersih (PAM) yang didukung jaringan pipa yang baik dan tidak bocor; Fasilitas parkir yang luas di lingkungan gedung pelayanan publik yang banyak dikunjungi masyarakat; Petunjuk-petunjuk arah 
yang jelas di luar maupun di dalam gedung pelayanan publik yang bertingkat dan memiliki banyak ruang dan lorong/koridor; Armada truk pengangkut sampah yang baik dan tertutup sehingga sampah yang diangkut tidak tercecer dan mengganggu kenyamanan anggota masyarakat di sepanjang jalur pengangkutan sampah tersebut; Pemanfaatan teknologi informatika (komputer dan telekomunikasi) dalam penyelenggaraan pelayanan publik oleh pemerintah daerah; dan sebagainya.

2. Barang/Jasa Pelengkap (Complimentary Products): Barang/jasa pelengkap yang dimaksud adalah barang atau material atau bisa juga dokumen, maupun jasa-jasa lainnya yang harus disediakan, dibeli, dan atau digunakan oleh masyarakat calon pengguna layanan publik sebagai pelengkap atau kelengkapan sebelum atau sesudah memperoleh pelayanan publik tertentu. Contoh material atau jasa pelengkap atau kelengkapan pelayanan publik tersebut antara lain: Pakaian renang yang digunakan saat berenang di kolam renang publik; Obat-obatan yang harus dibeli sesuai resep dari Dokter untuk menyembuhkan penyakit pasien sebuah Puskesmas; Surat rujukan (Referal) dari Puskesmas untuk memperoleh layanan Rumah Sakit; Dokumen sertifikat tanah serta gambar rencana bangunan sebagai kelengkapan memperoleh IMB; Akta jual beli tanah sebagai syarat memperoleh sertifikat hak atas tanah; Ijasah SD sebagai syarat untuk diterima di SMP; dan sebagainya.

3. Layanan Eksplisit (Explicit Services): Layanan eksplisit yang dimaksud adalah wujud nyata sebagai substansi atau inti manfaat dari pelayanan publik yang diterima atau dirasakan oleh masyarakat. Beberapa contoh layanan eksplisit adalah sebagai berikut: Rasa sakit yang berkurang (kesembuhan) setelah berobat ke Puskesmas atau RSUD; Meningkatnya keamanan kendaraan niaga/angkutan umum setelah memperoleh layanan "Kir Kendaraan” dari DLLAJ; Padamnya api kebakaran rumah dalam waktu singkat karena tindakan cepat dari aparat pemadam kebakaran dalam merespons laporan masyarakat; Lancarnya arus lalu lintas dalam kota setelah pemberlakuan kebijakan satu arah pada beberapa ruas jalan tertentu oleh DLLAJ; Ketepatan waktu terbitnya IMB sesuai yang dijanjikan; Meningkatnya angka kelulusan murid SD/SMP/SMU berkat peningkatan kedisiplinan para guru dalam melaksanakan tugas mengajar; Meningkatnya ketertiban dan keindahan kota setelah relokasi pedagang kaki lima; dan sebagainya.

4. Manfaat Tersirat (Implicit Benefits): Manfaat yang tersirat (implisit) dari pelayanan publik adalah manfaat yang secara psikologis dapat dirasakan oleh masyarakat secara ekstrinsik dari suatu layanan publik yang diselenggarakan oleh pemerintah daerah. Manfat tersebut antara lain sebagai berikut: Rasa aman mengkonsumsi air minum PDAM; Rasa aman dan tidak takut keruntuhan bangunan/rumah ber-IMB, karena telah diuji konstruksinya oleh pengawas bangunan; Rasa aman dan adanya kepastian hukum memiliki tanah bersertifikat hak milik; Rasa aman dan tidak takut menyekolahkan anak di SD Inpres yang dibangun sesuai bestek; Merasa sehat setelah memperoleh perawatan kesehatan di Puskesmas/RSUD; Rasa nyaman dan aman saat duduk-duduk di taman kota; Rasa aman mengkonsumsi daging sapi yang dibeli di pasar tradisional karena diawasi oleh Dinas Peternakan; dan sebagainya.

Berbagai prinsip kinerja dan kualitas penyelenggaraan pelayanan publik sebagaimana telah dikemukakan, memberikan gambaran secara ringkas apa yang perlu dipertimbangkan oleh Pemerintah Daerah dalam rangka memberikan kepuasan dan kepercayaan masyarakat atas pelayanan publik yang diselenggarakan selama ini. Pemahaman mengenai konsepsi, ruang, lingkup, prinsip-prinsip kinerja penyelenggaraan dan kualitas pelayanan publik tersebut di atas akan sangat membantu Pemerintah Daerah maupun Pemerintah Pusat dalam upaya peningkatan kapasitas aparatur daerah dalam penyelenggaraan pelayanan publik. Pada bagian tulisan berikutnya akan dibahas bagaimana konsepsi dan ruang lingkup peningkatan kapasitas aparatur daerah yang selanjutnya dapat dijadikan sebagai landasan kebijakan strategis yang 
dapat dipertimbangkan oleh Pemerintah Daerah untuk meningkatkan kinerja dan kualitas penyelenggaraan pelayanan publik di daerah.

\section{Peningkatan Kapasitas Penyelenggaraan Pelayanan Publik}

Pemerintah daerah otonom di Indonesia sesungguhnya sudah sangat berpengalaman dalam menyelenggarakan pelayanan publik sejak sebelum berlakunya UU Nomor 22 Tahun 1999, khususnya dalam kurun masa berlakunya UU No 5 Tahun 1974 Tentang Pokok-Pokok Pemerintahan di Daerah. Namun demikian dalam kerangka otonomi yang seluas-luasnya dalam penyelenggaraan pelayanan publik, Pemerintah Daerah secara praktis baru berpengalaman seumur jagung, yaitu sejak diberlakukannya UU Nomor 22 tahun 1999 pada awal tahun 2001, yang diperbaharui dengan pemberlakuan UU Nomor 32 Tahun 2004 pada bulan September 2004. Dengan kewenangan otonomi yang luas tersebut, Pemerintah Daerah memiliki keleluasaan wewenang untuk mengembangkan berbagai jenis dan bentuk, serta kualitas dan jangkauan pelayanan kepada masyarakat sesuai dengan bidang kewenangan wajib maupun pilihan yang telah didesentralisasikan kepada setiap daerah otonom, baik Propinsi, Kabupaten, maupun Kota.

Sangat disayangkan, dalam suasasana euforia otonomi daerah yang berlaku hampir di seluruh Nusantara, ternyata pelaksanaan penyelenggaraan pelayanan publik dalam 3 (tiga) tahun terakhir justru lebih sarat dengan muatan kepentingan Pemerintah Daerah untuk menggali sebesar-besarnya Pendapatan Asli Daerah (PAD). Hal ini dibuktikan dengan terbitnya sejumlah Peraturan Daerah yang mengatur dan menetapkan berbagai jenis pelayanan publik yang berimplikasi langsung pada perluasan objek dan subjek pajak dan retribusi daerah sebagai sumber peningkatan PAD. Ekspansi objek dan subjek perpajakan dan retribusi daerah yang dihasilkan melalui berbagai jenis pelayanan publik yang diselenggarakan oleh Pemerintah Daerah tersebut telah cenderung mendistrosi pasar yang berdampak pada terbentuknya biaya ekonomi tinggi.

Bank Dunia (World Bank), Kantor Perwakilan Indonesia di Jakarta dalam draft laporan kajian evaluatif tentang proses desentralisasi di Indonesia yang berjudul "Decentralizing Indonesia" (April, 2003), menyoroti adanya kecenderungan pemerintah daerah yang mengembangkan sistem perpajakan (termasuk sistem retribusi pelayanan publik) daerah yang kurang atau tidak mengabaikan prinsip-prinsip perpajakan yang baik sehingga cenderung mendistorsi mekanisme pasar dan mengakibatkan ekonomi biaya tinggi. Bank Dunia mengkritik kecenderungan perkembangan perpajakan daerah yang dilakukan Pemerintah Daerah itu justru menjadi disinsentif bagi sektor industri dan perdagangan, sehingga para investor enggan menanamkan modalnya di daerah. Hasil studi Komite Pemantau Pelaksanaan Otonomi Daerah (KPPOD) dalam laporan hasil kajiannya atas 1.025 Peraturan Daerah (Perda) dari berbagai Kabupaten/Kota memperoleh kesimpulan bahwa 30,2 \% dari Perda tersebut berpotensi mendistorsi pasar. Sedangkan laporan hasil survey KPPOD tahun 2004-2005 dalam rangka pemeringkatan daya saing investasi Kabupaten/Kota di Indonesia, antara lain mengindikasikan pendapat responden (24,6 \%) yang merasa bahwa Perda telah mendistorsi aktivitas sosial-ekonomi mereka (Media Otonomi, Edisi No. 7, Tahun I 2005, hal. 50-53). 
Fenomena penyelenggaraan pelayanan publik oleh Pemerintah Daerah dalam era otonomi dewasa ini, tentu saja tidak selalu negatif dalam konteks interaksinya dengan kepentingan masyarakat umum maupun dunia usaha. Di beberapa Daerah dapat ditemukan fakta bahwa kreativitas dan inovasi Pemerintah Daerah telah mampu meningkatkan kualitas maupun daya jangkau pelayanan publik yang sesuai bahkan lebih dari harapan dan aspirasi masyarakat, tanpa harus membebani masyarakat dengan ekonomi biaya tinggi.

Dewasa ini, untuk mengendalikan kecenderungan eksploitasi pelayanan publik sebagai sumber PAD yang potensial menyebabkan ekonomi biaya tinggi sebagaimana telah disebutkan, Pemerintah melalui UU Nomor 33 Tahun 2004, Pasal 7 huruf a dan b, telah melarang daerah untuk meningkatkan PAD melalui penetapan Perda tentang pendapatan yang menyebabkan ekonomi biaya tinggi, dan yang menghambat mobilitas penduduk, lalu lintas barang dan jasa antar daerah, serta kegiatan ekspor/ekspor. Adanya larangan tersebut diharapkan dapat meredam kecenderungan Pemerintah Daerah untuk menggali PAD melalui penyelenggaraan pelayanan publik yang cenderung mendistorsi aktivitas masyarakat dan dunia usaha. Namun demikian, pelarangan saja tanpa adanya sanksi yang jelas terhadap pelanggarannya oleh Pemerintah Daerah masih diragukan keefektivannya.

Mengingat PAD merupakan kebutuhan Pemerintah Daerah yang sangat vital untuk membiayai pelaksanaan kewenangan otonominya, sementara di sisi lain ada pula tuntutan aspirasi masyarakat untuk meringankan bahkan menghapuskan berbagai biaya atau retribusi atas pelayanan publik yang dibutuhkan; maka tampaknya persoalan yang sebenarnya dihadapi adalah bagaimana meningkatkan kapasitas aparatur daerah dalam penyelenggaraan pelayanan publik. Jadi bukan sekedar mengeluarkan larangan melalui mekanisme peraturan perundangundangan, apalagi jika tidak diimbangi dengan pemberian jalan keluar yang kondusif bagi daerah. Gagasan pengembangan atau peningkatan kapasitas aparatur daerah dalam penyelenggaraan pelayanan publik merupakan hal yang strategis untuk dikaji dan dipertimbangkan arah kebijakannya.

\section{Pengertian dan Ruang Lingkup Peningkatan Kapasitas (Capacity Building)}

Istilah kapasitas memiliki beragam pengertian tergantung siapa yang mengartikannya dan dalam konteks apa istilah tersebut akan digunakan. Permasalahan yang timbul dalam penggunaan istilah kapasitas tersebut di atas adalah kesulitan yang dihadapi dalam mengukur kapasitas aparatur pemerintah daerah, karena adanya perbedaan-perbedaan pandangan yang sering dilandasi oleh kepentingan politik maupun pertimbangan-pertimbangan teknis tertentu mengenai kemampuan aparatur pemerintah daerah dalam penyelenggaraan pelayanan bagi masyarakat. Sebagai contoh bagaimana Pemerintah Pusat dapat menilai bahwa kapasitas pemerintah daerah tertentu lemah dalam program pengentasan kemiskinan, sebagaimana ditunjukkan dari angka kemiskinan yang cenderung meningkat dari tahun ke tahun; padahal dari sisi pemerintah daerah yang bersangkutan statistik kemiskinan tersebut dapat berarti potensi turunnya program-program yang dibiayai oleh dana Pemerintah Pusat. 
Contoh tersebut menunjukkan bahwa menilai kapasitas tidak selalu mudah, dan akan tergantung kepada bagaimana cara memandang kapasitas tersebut. Dalam contoh di atas, Pemerintah memandang kapasitas sebagai kemampuan untuk menurunkan angka kemiskinan. Sedangkan dari sisi aparatur Pemerintah Daerah yang termaksud, kapasitas justru diartikan sebagai kemampuan untuk mendatangkan program-program yang didanai Pusat untuk mengatasi kemiskinan di daerah yang bersangkutan, karena mereka memiliki keterbatasan sumber-sumber keuangan daerah untuk melaksanakan program yang dimaksud. Perbedaan cara pandang inilah yang harus dihindarkan ketika kebijakan untuk meningkatkan kapasitas aparatur daerah dalam penyelenggaraan pelayanan publik harus dipertimbangkan dan dilaksanakan.

Untuk itu dalam tulisan ini akan dikemukan paling tidak dua pengertian kapasitas, pertama adalah pengertian sebagaimana dirumuskan oleh Peter Morgan (1998) sebagai berikut: "Kapasitas adalah kemampuan, ketrampilan, pemahaman, sikap, nilai-nilai, hubungan, perilaku, motivasi, sumber daya, dan kondisi-kondisi yang memungkinkan setiap individu, organisasi, jaringan kerja/sektor, dan sistem yang lebih luas untuk melaksanakan fungsi-fungsi mereka dan mencapai tujuan pembangunan yang telah ditetapkan dari waktu ke waktu”.

Dalam rumusan lain yang lebih sederhana UNDP (1998) memberikan pengertian tentang kapasitas sebagai berikut: "Kapasitas dapat diartikan sebagai kemampuan individu dan organisasi atau unit-unit organisasi untuk melaksanakan tugas pokok dan fungsinya secara efektif, efisien, dan berkelanjutan ...Kapasitas juga dapat diartikan dalam konteks sistem dimana suatu entitas bekerja untuk mencapai tujuan bersama berdasarkan proses dan aturan-aturan baku tertentu."

Dengan menggunakan pengertian yang lebih sederhana, dalam konteks penyelenggaraan pelayanan publik oleh pemerintah daerah maka dapat dikatakan bahwa kapasitas penyelenggaraan pelayanan publik adalah kemampuan pemerintah daerah, baik secara keseluruhan, unit-unit perangkat pemerintah daerahnya, maupun individu aparatur pemerintah daerah untuk menghasilkan kinerja dan kualitas layanan publik yang efektif, efisien dan berkelanjutan.

Dalam keterbatasan kemampuan untuk mengukur kapasitas penyelenggaraan pelayanan publik berdasarkan standar kinerja pelayanan publik yang memang belum secara tegas dimiliki baik dalam skala nasional maupun daerah, maka pendekatan untuk meningkatkan kapasitas aparatur daerah dalam penyelenggaraan pelayanan publik dapat digunakan tolok ukur normatif yaitu untuk menghasilkan kinerja yang lebih baik dari kondisi yang telah dicapai saat ini. Berdasarkan pendekatan tersebut, kertas kerja ini akan membahas bagaimana strategi untuk meningkatkan kapasitas aparatur daerah dalam penyelenggaraan pelayanan publik.

Peningkatan kapasitas atau yang lebih dikenal dengan istilah Capacity Building atau Capacity Development adalah suatu pendekatan, strategi dan metodologi yang digunakan oleh negara-negara berkembang dan/atau pihak-pihak luar yang berkepentingan untuk memperbaiki dan meningkatkan kinerja individu aparatur pemerintah, organisasi, jaringan 
kerja/sektor maupun sistem yang lebih luas dalam pencapaian tujuan fungsional tertentu (Joe Bolger, 2000).

Canadian International Development Agency (CIDA) dan berbagai lembaga donor lainnya cenderung memberikan pengertian peningatan kapasitas sebagai proses dimana para individu, kelompok, organisasi, institusi, dan masyarakat meningkatkan kemampuan mereka untuk: (1) menghasilkan kinerja pelaksanaan tugas pokok dan fungsi (core functions), memecahkan permasalahan, merumuskan dan mewujudkan pencapaian tujuan yang telah ditetapkan; dan (2) memahami dan memenuhi kebutuhan pembangunan dalam konteks yang lebih luas dalam cara yang berkelanjutan (UNDP, 1998).

Upaya peningkatan kapasitas (capacity building) bagi aparatur penyelenggara pelayanan publik di daerah sesuai dengan kebutuhan dan permasalahan yang dihadapi, dapat diidentifikasi dalam tiga tingkatan sebagai satu kesatuan yang utuh sebagaimana digunakan oleh UNDP sebagai pedoman dalam program peningkatan kapasitas, yaitu: Tingkat Sistem, Tingkat Entitas, dan Tingkat Individual.

\section{Peningkatan Kapasitas Pada Level Sistem.}

Pada tingkat sistem atau lingkungan yang lebih luas dan berpengaruh terhadap sistem penyelenggaraan pelayanan publik di daerah, peningkatan kapasitas penyelenggaraan pelayanan publik dapat diarahkan pada beberapa aspek sebagai berikut:

- Penyempurnaan dan perumusan kebijakan daerah yang mengarahkan pada tujuan penyelenggaraan pelayanan publik berdasarkan tuntutan aspirasi dan kepentingan masyarakat daerah yang bersangkutan

- Peninjauan kembali, penyempurnaan, dan perumusan ketentuan peraturan perundangundangan, termasuk sistem nilai dan standar-standar penyelenggaraan pelayanan publik di daerah, yang mengarahkan sistem penyelenggaraan pelayanan publik di daerah untuk berfungsi berdasarkan tingkatan kapasitas kinerja tertentu.

- Penyusunan dan pengembangan sistem manajemen dan sistem pertanggungjawaban (akuntabilitas) pada level sistem pemerintahan daerah, yaitu untuk menentukan bagaimana kinerja yang harus dicapai pada tingkat sistem pemerintahan daerah dalam merancang, mengelola, mengkoordinasikan, memonitor dan mengevaluasi kinerja penyelenggaraan pelayanan publik.

- Optimalisasi perencanaan sumberdaya yang tersedia pada tataran sistem pemerintahan daerah yang dapat digunakan untuk meningkatkan kinerja penyelenggaraan pelayanan publik di daerah yang bersangkutan.

- Optimalisasi efektivitas keberfungsian jaringan kerja lintas sektor dan antar kelembagaan (entitas) penyelenggara pelayanan publik dan pemerintahan di daerah, yang mencakup jaringan hubungan kerja, ketergantungan, maupun interaksinya secara formal maupun informal dalam penyediaan sumberdaya, arus informasi dan pelaporan, termasuk infrastruktur komunikasi.

\section{Peningkatan Kapasitas Pada Level Entitas atau Organisasi.}

Pada tingkat entitas kelembagaan penyelenggara pelayanan publik di daerah, upaya peningkatan kapasitas tidak semata-mata diarahkan pada sumberdaya yang tersedia dalam suatu lembaga penyelenggara pelayanan publik, tetapi juga kemampuan interaksinya 
dengan sistem pemerintahan dan masyarakat yang lebih luas serta interaksinya dengan para individu aparatur maupun masyarakat di lingkungan organisasi yang bersangkutan. Ruanglingkup strategi peningkatan kapasitas pada tingkat organisasi, adalah sebagai berikut:

- Pengembangan manajemen strategis organisasi penyelenggara pelayanan publik yang meliputi: tugas pokok dan fungsi, serta peranan organisasi dalam penyelenggaraan pelayanan publik tertentu, perumusan jenis barang dan jasa publik yang menjadi tanggungjawab organisasi tersebut, menetapkan siapa klien atau para pengguna layanan publik yang akan diselenggarakan, menetapkan hubungan kerja dan interaksi yang perlu dikembangkan dengan sistem pemerintahanyang lebih luas dan para stakeholders, penetapan parameter kinerja dan keberhasilan penyelenggaraan pelayanan publik yang dimaksud, serta perumusan kapasitas inti kinerja manajemen stratejik organisasi yang bersangkutan.

- Mengembangkan pola kompetensi, kultur dan struktur dalam organisasi yang mencakup: sistem nilai yang berlaku dalam organisasi dan manajemen, gaya manajemen yang akan dikembangkan, standar-standar operasi dan rancangan struktur hubungan dalam organisasi, serta perumusan kompetensi inti apa saja yang harus dimiliki dan dikuasi oleh organisasi untuk mampu melaksanakan tugas pokok dan fungsinya.

- Mengembangkan proses-proses termasuk prosedur kerja, dan mekanisme hubungan kerja baik ke dalam maupun ke luar, yang meliputi: proses perencanaan, pengelolaan hubungan masyarakat (Client Management and Public Relations), hubungan kerja dan koordinasi dengan organisasi lain, proses penelitian dan pengembangan, sistem monitoring dan evaluasi maupun sistem manajemen kualitas/ kinerja, pengelolaan keuangan, manajemen sumber daya manusia, dan sebagainya.

- Pengembangan suber daya manusia dalam organisasi, sebagai salah satu unsur yang sangat menentukan keberhasilan pencapaian kinerja dan kualitas pelayanan publik yang diselenggarakan oleh organisasi. Sumber daya manusia organisasi ini pula yang akan menentukan keberhasilan perubahan, kapasitas, dan perkembangan organisasi yang bersangkutan dalam melaksanakan tugas pokok dan fungsinya.

- Pengembangan kapasitas pengelolaan keuangan baik pembiayaan operasional maupun belanja modal (capital) yang diperlukan bagi tercapainya efektivitas dan efisiensi, serta produktivitas organisasi dalam penyelenggaraan pelayanan publik tertentu.

- Pengembangan kapasitas pengelolaan sumber daya informasi. Proses ini sangat penting dalam era informasi dewasa ini, sehingga organisasi harus mampu meningkatkan efektivitas pengelolaan berbagai media informasi sedemikian rupa sehingga mampu mendukung pencapaian visi dan misi pelayanan publik yang telah ditetapkan; dan bukan sebaliknya.

- Pengembangan kapasitas infrastruktur yang mencakup gedung kantor, tanah atau lahan, serta barang-barang bergerak lainnya yang menjadi kekayaan dan inventaris organisasi; termasuk berbagai peralatan dan perlengkapan perkantoran yang dimiliki berupa komputer, teknologi telematika, mesin fotocopy/percetakan, dan sebagainya yang digunakan untuk memperlancar proses penyelenggaraan pelayanan publik sesuai dengan karakteristik barang dan jasa publik yang akan dihasilkan.

\section{Peningkatan Kapasitas Pada Level Individu}

Program peningkatan/pengembangan kapasitas pada level individu sebenarnya tidak terbatas kepada aparatur pelaksana pelayanan publik pada organisasi tertentu; melainkan 
termasuk juga individu masyarakat sebagai pengguna atau penerima manfaat pelayanan publik yang diselenggarakan oleh organisasi pemerintah daerah tertentu. Pada tataran individu dalam organisasi, upaya peningkatan kapasitas penyelenggaraan pelayanan publik diarahkan bagi semua tingkatan manajemen dari unsur pimpinan puncak hingga eselon terendah dan para petugas operasional sesuai dengan kompetensi masing-masing berdasarkan analisis jabatan dan uraian tugas yang menjadi tanggungjawab masingmasing. Pengembangan kapasitas dalam hal ini mencakup nilai-nilai profesionalisme dan ketrampilan kerja serta wawasan yang diperlukan dalam interaksi dengan masyarakat pengguna layanan publik, serta dalam pencapaian kinerja dan kualitas pelayanan publik sesuai dengan standar-standar kinerja yang telah ditetapkan sebelumnya. Sedangkan bagi masyarakat pengguna, peningatan kapasitas dapat mencakup kemampuan bagi masyarakat untuk berperan aktif dalam penyelenggaraan pelayanan publik, optimalisasi manfaat layanan publik yang diterima, maupun dalam memberikan informasi pengendalian kualitas dan tingkat kepuasan masyarakat terhadap layanan yang mereka terima.

Keseluruhan upaya peningkatan kapasitas penyelenggaraan pelayanan publik dalam ketiga tingkatan tersebut, dapat digambarkan dalam bagan sebagai berikut:

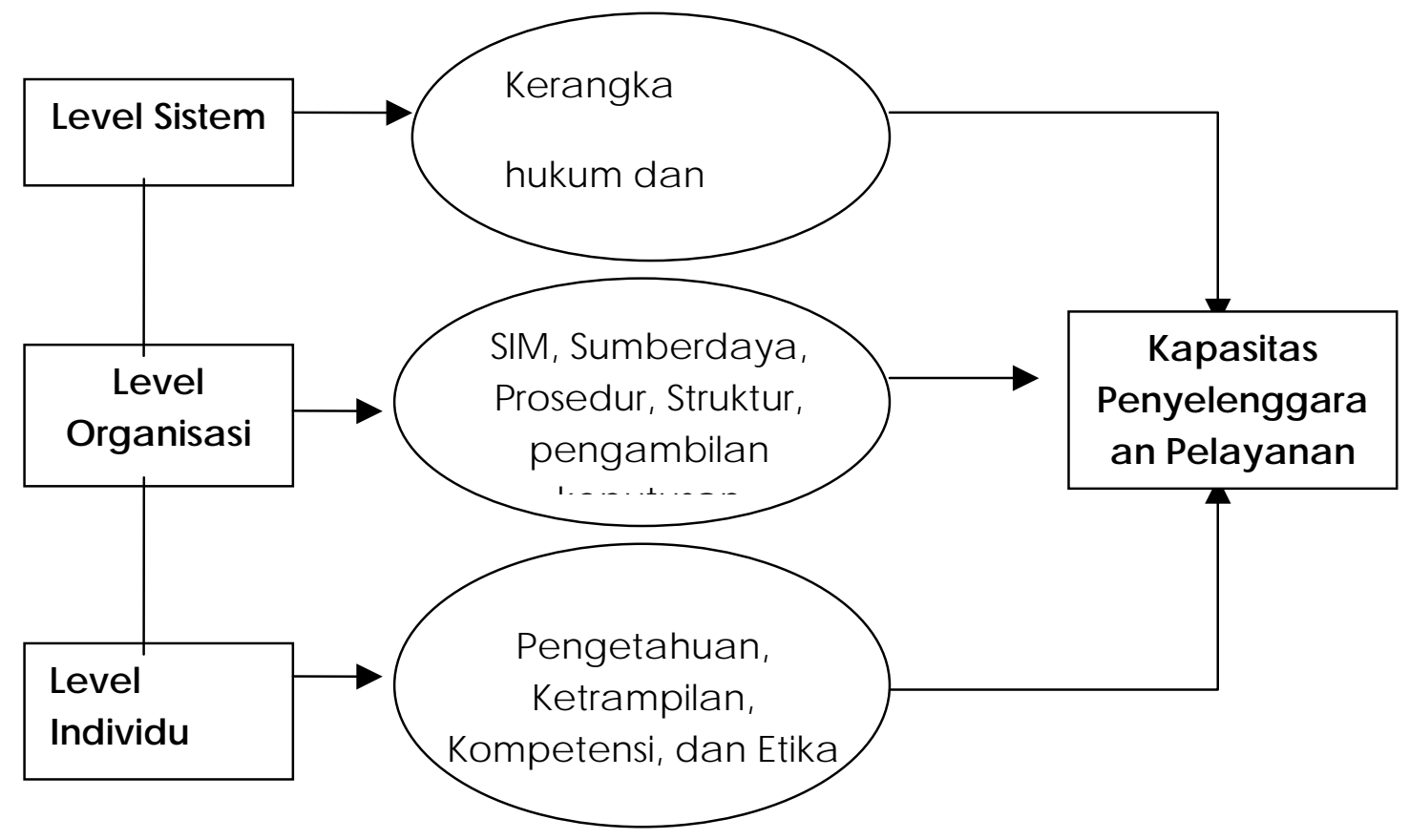

Gambar 1

Kerangka Peningkatan Kapasitas Penyelenggaraan Pelayanan Publik

Berdasarkan kerangka tersebut di atas, maka dalam upaya peningkatan kapasitas aparatur dalam penyelenggaraan pelayanan publik jelas tidak hanya terbatas kepada upayaupaya atau program-program pelatihan bagi para aparatur pelaksana pelayanan publik sematamata, melainkan termasuk strategi kebijakan pengembangan sistem hukum dan perundangundangan daerah yang mendukung pelaksanaannya, serta penataan sistem kelembagaan organisasi penyelenggara pelayanan publik yang dimaksud.

Sejalan dengan langkah strategi yang perlu dikembangkan oleh pemerintah daerah dalam rangka meningkatkan kapasitas penyelenggaraan pelayanan publik, kiranya daftar periksa (cheklist) untuk mendiagnosa kondisi paket pelayanan publik yang ada dapat 
dipertimbangkan sebagai instrumen awal, sebagaimana terlihat dalam Tabel 1 pada lampiran kertas kerja ini.

Pada awal era reformasi dan otonomi daerah pada tahun 1998, Menteri Koordinator Pengawasan Pembangunan dan Pendayagunaan Aparatur Negara (Menko Wasbang PAN) telah mengeluarkan Surat Edaran Nomor 56/MK.WASPAN/6/98 Tentang Pelayanan Kepada Masyarakat, di tetapkan bahwa seluruh Menteri Kabinet Reformasi Pembangunan, Gubernur Bank Indonesia, Para Gubernur seluruh Indonesia, para pimpinan Lembaga Pemerintah NonDepartemen, dan para Bupati/Waikota seluruh Indonesia untuk melaksanakan beberapa langkah kebijakan dalam rangka meningkatkan kapasitas penyelenggaraan pelayanan publik oleh pemerintah, pemerintah daerah maupun BUMN dan BUMD sebagai berikut:

1. Dalam waktu secepat-cepatnya mengambil langkah-langkah perbaikan mutu pelayanan masyarakat pada masing-masing unit kerja/kantor pelayanan termasuk BUMN/BUMD

2. Langkah-langkah perbaikan mutu pelayanan masyarakat tersebut diupayakan dengan:

- Menerbitkan pedoman pelayanan yang antara lain memuat persyaratan, prosedur, biaya/tarif pelayanan dan batas waktu penyelesaian pelayanan, baik dalam bentuk buku panduan/ pengumuman, atau melalui media informasi lainnya.

- Menempatkan petugas yang bertanggung jawab melakukan pengecekan kelengkapan persyaratan permohonan untuk kepastian mengenai diterima atau ditolaknya berkas permohonan tersebut pada saat itu juga.

- Menyelesaikan permohonan pelayanan sesuai dengan batas waktu yang ditetapkan, dan apabila batas waktu yang telah ditetapkan terlampaui maka permohonan tersebut berarti disetujui.

- Melarang dan atau menghapus biaya tambahan yang dititipkan pihak lain dan meniadakan segala bentuk pungutan liar, di luar biaya jasa pelayanan yang telah ditetapkan.

- Sedapat mungkin menerapkan pola pelayanan secara terpadu (satu atap atau satu pintu) bagi unit-unit kerja kantor pelayanan yang terkait dalam proses atau menghasilkan satu produk pelayanan.

- Melakukan penelitian secara berkala untuk mengetahui kepuasan pelanggan/masyarakat atas pelayanan yang diberikan, antara lain dengan cara penyebaran kuesioner kepada pelanggan/masyarakat dan hasilnya perlu dievaluasi dan ditindak lanjuti.

- Menata sistem dan prosedur pelayanan secara berkesinambungan sesuai dengan tuntutan dan perkembangan dinamika masyarakat.

3. Pemerintah membuka kesempatan yang seluas-luasnya kepada masyarakat baik langsung maupun media massa untuk menyampaikan saran dan atau pengaduan mengenai pelayanan masyarakat.

Meskipun Surat Edaran tersebut mungkin dewasa ini sudah dianggap kedaluwarsa, namun dari sudut substansinya materi surat tersebut tampaknya masih relevan sebagai dasar pertimbangan langkah-langkah yang perlu dilakukan oleh pemerintah daerah dalam rangka peningkatan kapasitas penyelenggaraan pelayanan publik. 


\section{Daftar Pustaka}

Edvardsson, Bo, Bertil Thomasson, and John Ovretveit, 1994, Quality of Service: Making it Really Work, McGraw-Hill Book Company, London.

Fitzsimmons James A, and Mona J. Fitzsimmon, 1994, Service Management For Competitive Advantage, McGraw-Hill International, Singapore.

Hildebrand, Mary E dan Merilee S Grindle, 1994, "Building Capacity: Challenge for Public Sector”, Harvard University, November 1994

Moenir, H.A.S., 1998, Manajemen Pelayanan Umum di Indonesia, Bumi Aksara, Jakarta.

Rohdewohld, Rainer, Building Capacity To Support Decentralization - The Case of Indonesia (1999-2004), Paper prepared for The Tokyo International Syposium On Capacity Development, Tokyo, 4-6 February 2004.

Savas, ES., 1987, Privatization: The Key To Better Government, Chatham House Publishers Inc., New Jersey.

UNDP, 1998, "Capacity Assessment and Development in a Systems and Strategic Management Context”, Technical Advisory Paper No. 3, New York.

Zeitaml, Valarie A. et.al., 1990, Delivering Quality Service: Balancing Customer Perceptions and Expectations, The Free Press, New York.

Undang- Undang Nomor 22 Tahun 1999 Tentang Pemerintahan Daerah

Undang-Undang Nomor 32 Tahun 2004 Tentang Pemerintahan Daerah

Undang-Undang Nomor 33 Tahun 2004 Tentang Perimbangan Keuangan Antara Pusat dan Daerah.

Instruksi Presiden RI Nomor 1 Tahun 1995 Tentang Peningkatan Kualitas Pelayanan Aparatur Pemerintah Kepada Masyarakat.

Keputusan Menpan Nomor 81 Tahun 1993 Tentang Pedoman Tata Laksana Pelayanan Umum.

Keputusan Menteri Pendayagunaan Aparatur Negara (MenPAN) nomor 63/KEP/M.PAN/7/ 2003

Surat Edaran Menko WASBANG PAN Nomor 56/ MK.WASPAN/6/98 Tentang Pelayanan Kepada Masyarakat 